\title{
Evaluating concordance with the 1997 World Cancer Research Fund/American Institute of Cancer Research cancer prevention guidelines: challenges for the research community
}

\author{
Marieke Vossenaar ${ }^{1,2}$, Noel W. Solomons ${ }^{1}$, Roxana Valdés-Ramos ${ }^{3}$ and Annie S. Anderson ${ }^{2 *}$ \\ ${ }^{1}$ Center for Studies of Sensory Impairment, Aging and Metabolism (CeSSIAM), Guatemala City, Guatemala \\ ${ }^{2}$ Centre for Public Health Nutrition Research, University of Dundee, Ninewells Hospital and Medical School, Dundee \\ DD1 9SY, UK \\ ${ }^{3}$ Facultad de Medicina, Universidad Autónoma del Estado de Mexico, Jesus Carranza esq. Paseo Tollocan, Col. Moderna de \\ la Cruz, Toluca, Estado de Mexico, 50180, Mexico
}

\begin{abstract}
Diet, nutritional status and lifestyle practices are significant determinants of the risk of certain cancers. In 1997 The World Cancer Research Fund/American Institute for Cancer Research (WCRF/AICR) developed a series of evidence-based recommendations to help reduce the population and individual risk of cancer. However, guidance for evaluating concordance or compliance with these recommendations is limited. To illustrate the challenges in evaluation, four publications were reviewed that explored the task of creating operative criteria from which to assess concordance with the tenets of the WCRF/AICR recommendations. Three documents dealt with secondary analysis, whereas one was a prospective inquiry, with procedures and instruments designed to obtain responses to WCRF/AICR cancer-prevention specification. One considered only population-goal criteria, and two dealt implicitly or explicitly with criteria at both population and individual levels. The assessment approaches used by the authors were compared with alternative semantic and conceptual interpretations of the WCRF/AICR population goals and individual guidelines. Attempts to develop operative criteria for assessment of concordance (reflecting either a more superficial or more in-depth parsing of recommendations) have been inconsistent. The results indicate that the language of the WCRF/AICR leaves a certain degree of semantic ambiguity for evaluation purposes. Future design of prospective studies for analyses of behaviours and relevant exposures (including those reported in the 2007 WCRF/AICR report) should carefully consider evaluation criteria and fully document detailed methodology.
\end{abstract}

Diet: Physical activity: Body size: Cancer prevention: Assessment: World Cancer Research Fund/American Institute for Cancer Research

\section{Introduction}

Cancer is the second leading cause of premature adult death across the globe ${ }^{(1)}$. It is the result of an interaction of factors of genetic susceptibility with environmental exposures. Uauy \& Solomons ${ }^{(2)}$ list those environmental factors as 'exposure to ionizing radiation, specific infectious agents, microbial toxins, dietary factors and contaminants in food, water, and air'. An individual's risk is largely determined by the aforementioned exposures in addition to lifestyle behaviours. Moreover, cancer is not only a concern of affluent, developed societies. According to predictions summarised by Mellstedt ${ }^{(3)}$ : 'The burden of cancer is increasing globally, with an expected 20 million new cases per year in 2020, half of which will be in low- and middleincome countries.'

The aspects of dietary and eating behaviour, along with other modifiable risk factors of lifestyle implicated in cancer, were the basis for the 1997 Expert Report by the World Cancer Research Fund and American Institute of Cancer Research (WCRF/AICR), Food, Nutrition and the Prevention of Cancer: A Global Perspective ${ }^{(4)}$ and the more recent update published in $2007^{(5)}$. The panel of experts identified, reviewed and synthesised the extant biological and epidemiological literature leading up to its publication using a transparent and practical classifi-

Abbreviations: EAR, estimated average requirement; WCRF/AICR, World Cancer Research Fund/American Institute for Cancer Research. * Corresponding author: Professor Annie S. Anderson, fax + 441382 496452, email a.s.anderson@dundee.ac.uk 


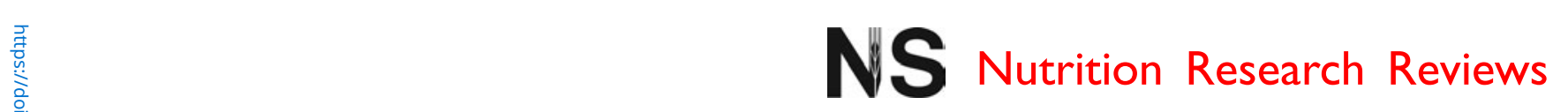

Table 1. The cancer prevention recommendations from the World Cancer Research Fund/American Institute of Cancer Research (WCRF/AICR) report ${ }^{\star}$, as expressed at the population-goal and individual-guideline levels

Recommendation

1. Food supply and eating

2. Maintaining body weight

3. Maintaining physical activity

4. Vegetables and fruits

5. Other plant foods

6. Alcoholic drinks

7. Meat

8. Total fats and oils

9. Salt and salting

10. Storage

11. Preservation

12. Additives and residues

13. Preparation

14. Dietary supplements

Tobacco

Population goal

Population to consume nutritionally adequate and varied diet, based primarily on foods of plant origin

Population average body mass indices throughout adult life to be within range $\mathrm{BMI} 21-23 \mathrm{~kg} / \mathrm{m}^{2}$ in order that individual $\mathrm{BMl}$ be maintained between 18.5 and $25 \mathrm{~kg} / \mathrm{m}^{2}$

Population to maintain, throughout life, an active lifestyle equivalent to a physical activity level (PAL) of at least 1.75, with opportunities for vigorous physical activity

Promote year-round consumption of a variety of vegetables and fruits providing $7 \%$ or more total energy

A variety of starchy or protein-rich foods of plant origin, preferably minimally processed, to provide $45-60 \%$ total energy. Refined sugar to provide less than $10 \%$ of total energy

Consumption of alcohol is not recommended. Excessive consumption of alcohol to be discouraged. For those who drink alcohol, restrict it to less than $5 \%$ total energy for men and less than $2.5 \%$ total energy for women If eaten at all, red meat to provide less than $10 \%$ total energy

Total fats and oils to provide $15 \%$ to no more than $30 \%$ total energy

Salt from all sources should amount to less than $6 \mathrm{~g} / \mathrm{d}$ ( 0.25 ounces)

for adults
Store perishable food in ways that minimise fungal contamination

Perishable food, if not consumed promptly, to be kept frozen or chilled

Establish and monitor the enforcement of safety limits for food additives, pesticides and their residues, and other chemical contaminants in the food supply

When meat and fish are eaten, encourage low temperature cooking

Community dietary pattern to be constituent with reduction of cancer risk without the use of dietary supplements

Discourage production and promotion

\section{Individual guideline}

Choose predominantly plant-based diets rich in a variety of vegetables and fruits, pulses (legumes) and minimally processed starchy staple foods Avoid being underweight or overweight and limit weight gain during adulthood to less than $5 \mathrm{~kg}$ (11 pounds)

If occupational activity is low or moderate, take an hour's brisk walk or simila exercise daily, and also exercise vigorously for a total of at least one hour in a week

Eat $400-800 \mathrm{~g}$ (15-30 ounces) or five or more portions (servings) a day of a variety of vegetables and fruits, all year round

Eat $600-800 \mathrm{~g}$ (20-30 ounces) or more than seven portions (servings) a day of a variety of cereals (grains), pulses (legumes), roots, tubers and plantains. Prefer minimally processed foods. Limit consumption of refined sugar

Alcohol consumption is not recommended. If consumed at all, limit alcoholic drinks to less than two drinks a day for men and one for women

If eaten at all, limit intake of red meat to less than $80 \mathrm{~g}$ ( 3 ounces) daily. It is preferable to choose fish, poultry or meat from non-domesticated animals in place of red meat

Limit consumption of fatty foods, particularly those of animal origin. Choose modest amounts of appropriate vegetable oils

Limit consumption of salted foods and use of cooking and table salt. Use herbs and spices to season foods

Do not eat food which, as a result of prolonged storage at ambient temperatures, is liable to contamination with mycotoxins

Use refrigeration and other appropriate method to preserve perishable food as purchased and at home

When levels of additives, contaminants and other residues are properly regulated, their presence in foods and drinks is not known to be harmful. However, unregulated or improper use can be a health hazard, and this applies particularly in economically developing countries

Do not eat charred food. For meat and fish eaters, avoid burning of meat juices. Consume the following only occasionally: meat and fish grilled (broiled) in direct flame; cured and smoked meats

For those who follow the recommendations presented here, dietary supplements are probably unnecessary, and possibly unhelpful for reducing cancer risk

Do not smoke or chew tobacco

* Reproduced from the 1997 WCRF/AICR report Diet, Nutrition and Prevention of Human Cancer: A Global Perspective ${ }^{(4)}$. 
Table 2. Short description of the three publications ${ }^{(6-8)}$ and one doctoral thesis ${ }^{(9)}$ which addressed the process of operationalising evaluation criteria from the World Cancer Research Fund/American Institute for Cancer Research (WCRF/AICR) recommendation series ${ }^{(4)}$

Reference

$$
\text { Title }
$$

Description

Valdes-Ramos et al. (2001) ${ }^{(8)} \quad$ Can the degree of concordance with recommendations for a cancer prevention diet and lifestyle be assessed from existing survey information data?

Valdes-Ramos et al. (2006) $)^{(7)}$

Concordance of diets and eating practices in a rural Guatemalan setting with the cancer prevention recommendations of the World Cancer Research Fund: estimates from existing dietary intake

Cerhan et al. (2004) $)^{(6)}$

Vossenaar (2005) ${ }^{(9)}$
Adherence to the AICR cancer prevention recommendations and subsequent morbidity and mortality in the lowa Women's Health Study cohort

Concordance with global dietary and lifestyle recommendations to reduce cancer risk in two European populations
The authors ${ }^{(20)}$ parsed the WCRF/AICR recommendations ${ }^{(4)}$ to determine to what extent relevant information on individual behaviour could be assessed from conventional FFQ. The questionnaire from the field survey had eighty-eight food and beverage items and was based on the Willett format ${ }^{(21)}$. The case-control study involved a similar FFQ with ninety food and beverage items and physical measurements of height and weight were available in the recommendations. Archival forms completed during two independent studies (a case-control and a field study) conducted in Guatemalan convenience samples were analysed. The findings provided a view of the possibilities and limitations of evaluating concordance with the 1997 WCRF/AICR recommendations in archival data for studies not prospectively designed for their evaluation

The authors analysed the series of survey forms collected on 269 adult Guatemalans of both sexes living in a township and surrounding hamlets in the eastern highlands Santa Rosa Province for the concordance of diet, behaviour and exposures with the six of 1997 WCRF/AICR recommendations ${ }^{(4)}$ (including eleven components) that they found feasible to evaluate. The questionnaire had eighty-eight food and beverage items and was based on the Willett format ${ }^{(21)}$. The purpose was to describe group-level concordance with the population goals of the WCRF/AICR report

In an article published in 2004, the degree of concordance with a selected group of nine of the 1997 WCRF/AICR recommendations ${ }^{(4)}$ (in addition to tobacco use) was evaluated in a cohort of 29564 women aged 55 to 69 years living in the farming state of lowa in the central plains of the USA which had been followed for a decade at the time of the analysis. A semi-quantitative FFQ including 127 food items developed by Willett et al. ${ }^{(21)}$ was used. Data on self-reported weight were collected at baseline. Physical activity was determined using a physical activity index ${ }^{(22)}$. The aim of the study was to relate adherence to the WCRF/AICR recommendations to cancer incidence cancer mortality, CVD mortality, and total mortality, and the cohort was followed for more than a decade. The authors were exclusively interested in followed for more than a decade. The authers we w individual classification of concordance and ignored the concordance of the population

Vossenaar, in a doctoral thesis submitted to the University of Dundee in 2005, set out to examine concordance of two population samples (Dutch and Scottish) with the WCRF/AICR recommendations in a study prospectively designed to include as variables the widest range of recommendations (ten recommendations plus tobacco use) and twenty-nine of the subcomponents that could be parsed and made into operative criteria from the 1997 WCRF/AICR report ${ }^{(4)}$. Both population goals and individual guideline were evaluated in convenience samples of 1053 Dutch adults indivive and 849 Scoltish adults of both sexes. The examined behaviours included total diet (semi-quantitative FEQ with sixty and 107 items for the Dutch and Scottish sample respectively), food preparation techniques (such as baking of meat, frequency of barbequing meat), weight history, use of supplements and physical activity. The aim was to describe concordance in convenience samples from two Northern European sites with the luxury of prospective designing of the data-collection instrument

This thesis was part of the four-nation Concordance Project which was funded by a grant (no. 1999/56) from the WCRF for the year 2000 to 2002 entitled: 'Concordance with the provision of the WRCF/AICR guidelines on prevention of cancer in Northern Europe and MesoAmerica: comparative insights for cancer risk and its reduction' 
cation system for the importance on cancer incidence of distinct exposures and food and beverage consumption. The centrepiece of the 1997 publication became a series of fifteen recommendations to guide populations and individuals to reduce the risk of incident cancer. These are summarised in Table 1. It is pertinent to note that whilst the 2007 recommendations differ, the general considerations still apply (as indeed they do for similar recommendations for prevention of other chronic diseases).

On the public health education side, the challenge became that of promoting awareness of and compliance with the tenets of the recommendations of the report. However, there are questions about priorities of effort and emphasis in relationship to the manifestations of risky behaviours and exposures that may be relevant to a given group of individuals. It is, however, clear that identifying current behaviours is an important starting point for the development, implementation and evaluation of public health campaigns and to assess trends in behaviours and exposures over time.

To date, publications attempting to rationalise operative criteria for evaluation of the recommendations (Table 1) have been limited in number and it is timely to take stock of these experiences, particularly in that they have been used in different geographical and cultural settings.

\section{Methods}

To illustrate the challenges in evaluation, four publications ${ }^{(6-9)}$ were reviewed that explored the task of creating operative criteria from which to assess concordance with the tenets of the 1997 WCRF/AICR recommendations ${ }^{(4)}$. A summary of the four publications and their contributions to developing operative criteria to assess concordance with the WCRF/AICR recommendations ${ }^{(4)}$ is provided in Table 2.

\section{Selective $v$. universal inquiry into the World Cancer Research Fund/American Institute for Cancer Research recommendations}

There are at least fifty aspects of the WCRF/AICR recommendations which can be identified for evaluation that have no clear guidance on assessment methodology (see Appendix 1). In the initial parsing of the WCRF/AICR recommendations and planning of instrument development, the investigators of the four-nation Concordance Study ${ }^{(9)}$ (Table 3 ) set out all of the fifteen major and fifty-two minor elements as criteria from which operative criteria could potentially be made (shown in the first two columns of the matrix in Appendix 1). Once the data of the two European sites were analysed ${ }^{(9)}$, the operationalisation criteria developed were adapted to the four geographical sites (i.e. the Netherlands, Scotland, Mexico and Guatemala).

The matrix developed by Valdés-Ramos et al. ${ }^{(8)}$, examining the data available from a survey and a case-control study, determined that between ten and eleven elements could be evaluated (Table 3). These were generally based on the criteria boundaries of the population goals of the WCRF/ $\mathrm{AICR}^{(4)}$. Omitted from consideration among the original WCRF/AICR recommendation levels were those related to salt, fungal contamination, spoiling, chemical contamination, charring of fish and meat, and dietary supplements.
Cerhan et al. (6) set forth the components of the recommendations to be assessed in the women from the Iowa cohort in tabular form (Table 4). These were developed from both the individual guidelines and population goals of the WCRF/AICR ${ }^{(4)}$. They included nine of a possible fifteen levels, with conscious omission of recommendation 'Food supply and eating' and recommendations 10 to 14 (i.e. 'storage', 'preservation', 'additives and residues', 'preparation' and 'dietary supplements'). Recommendation 1 partly overlaps with recommendation 4 'vegetables and fruits' and 5 'other plant foods', so that it is partly covered.

\section{Evaluation criteria for population goals}

The population-level recommendations of the WCRF /AICR $^{(4)}$ are expressed as goals for populations. ValdésRamos et al. ${ }^{(7)}$ with archival data from a Guatemala field survey and Vossenaar ${ }^{(9)}$ with the prospective inquiry in the two European sites of the Concordance Study ${ }^{(9)}$ used as operative criteria the numerical target goals of the WCRF/ $\mathrm{AICR}^{(4)}$. They compared sample means with the population goals, an approach recommended by Nishida et al. ${ }^{(10)}$ and described in detail below. Because of their specific interest in individual classification, Cerhan et al. ${ }^{(6)}$ did not use this level of classification.

In each of the two-nation Concordance Study (Vossenaar ${ }^{(9)}$ ) and the Santa Rosa Study (Valdés-Ramos et al. ${ }^{(7)}$ ) a total of seven population goals (or their subcomponents) were examined, six of these being common to both studies. For five of these goals, evaluation methods and cut-off criteria used were similar. These included five of the recommendations with quantitative goals for food items as energy percentage (i.e. 'to consume $45-60 \%$ of energy from starchy or protein-rich foods of plant origin'; 'refined sugar to provide $<10 \%$ of energy'; 'to restrict intake of alcoholic drinks to less than $5 \%$ total energy for men and less than $2.5 \%$ total energy for women'; 'red meat (beef, lamb, pork) to provide $<10 \%$ of energy'; 'total fats and oils to provide $15 \%$ to no more than $30 \%$ total energy').

The recommendation 'to consume nutritionally adequate diets' was examined in both studies, but twelve micronutrients were examined in the two-nation Concordance $v$. eight in the Santa Rosa study ${ }^{(7)}$. In addition, different nutrient adequacy criteria were used.

In addition, Vossenaar ${ }^{(9)}$ assessed the BMI goal (i.e. 'population average body mass indices throughout adult life BMI 21-23 (individual 18.5-25))' and Valdés-Ramos et al. ${ }^{(7)}$ assessed vegetable and fruit consumption (i.e. 'to consume $\geq 7 \%$ of energy from vegetables and fruits').

\section{Evaluation criteria for individual guidelines}

The individual WCRF/AICR guidelines (see Table 1) were partly evaluated, along with population goals, in the Iowa study $^{(6)}$ and the two-nation Concordance Project analysis ${ }^{(9)}$. There was both homology and discrepancy in the application of criteria.

The individual guideline components evaluated by both authors were six in total. Of these, four were assessed using the same evaluation method (i.e. "consume five or more portions of vegetables and fruits a day'; 'consume 600-800 
grams of cereals, pulses, roots, tubers and plantains'; 'limit alcoholic drinks to less than two drinks a day for men and one for women'; 'limit intake of red meat to less than 80 grams daily'). However, of these four, only two were assessed using the same cut-off criteria. For example, for the recommendation to "consume five or more portions of vegetables and fruits a day' the Iowa study used five servings per $d$ as the cut-off value without specifying portion sizes, whereas the two-nation Concordance Study ${ }^{(9)}$ used portions per $\mathrm{d}$ and set the portion size at $80 \mathrm{~g}$. For the recommendation to 'consume 600-800 grams of cereals, pulses, roots, tubers and plantains' the Iowa study set the cut-off value at $400 \mathrm{~g}$ whereas the two-nation Concordance Study ${ }^{(9)}$ had a lower limit of $600 \mathrm{~g}$ and an upper limit of $800 \mathrm{~g}$.

The recommendation to 'limit weight gain during adulthood to less than $5 \mathrm{~kg}$ ' was assessed as weight gain since age 18 years by both Cerhan et al. ${ }^{(6)}$ and Vossenaar ${ }^{(9)}$. In addition, Vossenaar ${ }^{(9)}$ used weight gain in the previous 10 years as a proxy for weight gain during adulthood. Further details are provided in Appendix 1.

Because the Concordance Study ${ }^{(9)}$ was prospectively designed to evaluate the WCRF/AICR recommendations ${ }^{(4)}$, the study was able to incorporate the evaluation of a wider range of detail and nuance than could be derived from standard food intake investigations. An additional eleven recommendation components at the individual level were evaluated. A total of four recommendations ('food supply and eating' (recommendation 1); 'maintaining physical activity' (recommendation 3); 'preparation' (recommendation 13); 'dietary supplements' (recommendation 14)) were only assessed by $\operatorname{Vossenaar}^{(9)}$ and most of the subcomponents were included.

\section{Experience using the population-goal criteria as cut-off criteria for individual concordance}

A hybrid format for evaluation was used by all three investigations $^{(6,7,9)}$ and was created by applying the WCRF/ AICR population-goal criterion (Table 1), to individual subjects in the study, in order to classify each individual as being inside or outside of the recommended range. In fact, these criteria are population goals to be applied as target averages in relation to the mean of variables assessed at a whole-population level. However, the authors generated prevalences or frequencies of individuals 'non-concordant' with the population cut-off criteria. We have named this pseudo-individualisation of population goals. In Appendix 1 this form of analysis has been indicated below the population-goal recommendation where appropriate as 'Pseudo-individualised population goal'.

Nishida et al. ${ }^{(10)}$ came to grips with population goals (Fig. 1) in the context of the WHO/FAO consultancy that produced Technical Report 916 Diet, Nutrition and the Prevention of Chronic Disease ${ }^{(11)}$. Their concept is related to the issue of nutrient-intake goals for a population, which in turn are 'based on the assumption that the first priority is to ensure national food security and equity of distribution of available food in accordance with individual needs'. This approach is essentially analogous to the concept of estimated average requirements (EAR) of the US dietary reference intake ${ }^{(12)}$. Nishida et al. ${ }^{(10)}$ addressed the potential consequences and distortion if the population-goal values are applied as individual criteria as described above. They state 'the Joint WHO/FAO Expert Consultation stressed that because population nutrient intake goals refer to population averages, the aggregate change would be substantially greater than intended if they were to be applied to the diets of individuals'.

The concept of population goals as they applied to 'healthful eating' to reduce the risk of cancer, however, are much more nuanced. For fruits and vegetables (recommendation 4), there is a strong analogy to an essential nutrient's intake goal, in which the target is something to be achieved for a positive end. Conversely, the goals with respect to sugar (recommendation 5d), alcohol (recommendation 6) and red meat (recommendation 7) are clearly not about nutrient or food security, but in the domain of tolerance of potentially harmful dietary substances. It is not to 'achieve' the target goal, but rather not to exceed it. In fact, this is closely aligned to free sugar and SFA, which are nutrients more of concern for their undesirable effects than their essentiality.

The WCRF/AICR population goals expressed as a numerical range (as for other plant foods (recommendation 5) and total fats and oils (recommendation 8)) are a species of hybrid, which recognise an essentiality (obligating a certain intake level) but also potential harm when consumed in excess.

All three studies ${ }^{(6,7,9)}$ engaged in this pseudo-individualisation of population goals for recommendations. Cerhan et al. ${ }^{(6)}$ used this approach to assess individual concordance with four population-goal components. These were: 'population average body mass indices throughout adult life BMI 21-23 (individual 18.5-25)' (recommendation 2); 'active lifestyle equivalent to a physical activity level (PAL) of at least 1.75 ' (recommendation 3 ); 'total fats and oils to provide $15 \%$ to no more than $30 \%$ total energy' (recommendation 8); 'salt from all sources should amount to less than 6 grams/day for adults' (recommendation 9).

Valdés-Ramos et al. ${ }^{(7)}$ used the pseudo-individualisation approach for six components. These were: 'to consume nutritionally adequate diets' (recommendation 1); 'to consume $45-60 \%$ of energy from starchy or protein-rich foods of plant origin' (recommendation 5); 'refined sugar to provide $<10 \%$ of energy' (recommendation 5); 'to restrict intake of alcoholic drinks to less than $5 \%$ total energy for men and less than $2.5 \%$ total energy for women' (recommendation 6); 'red meat (beef, lamb, pork) to provide $<10 \%$ of energy' (recommendation 7 ); 'total fats and oils to provide $15 \%$ to no more than $30 \%$ total energy' (recommendation 8).

The above approach was used in the two-nation Concordance Study ${ }^{(9)}$ where it was used to assess eleven population-goal components. These included the components evaluated by Cerhan et al. ${ }^{(6)}$ and Valdés-Ramos et al. ${ }^{(7)}$ described above (with the exclusion of $1 \mathrm{a}$ and salt) and the following population goals: 'to consume varied diets' (recommendation 1); 'to consume $\geq 7 \%$ of energy from vegetables and fruits' (recommendation 4); 'to 
consume a variety of starchy or protein-rich foods of plant origin' (recommendation 5); 'when meat and fish are eaten, encourage relatively low temperature cooking' (recommendation 13). The only component evaluated in this manner by all three authors was the population goal for 'total fats and oils to provide $15 \%$ to no more than $30 \%$ total energy' (recommendation 8). The reason for this approach is that the individual guidelines for fat do not include quantitative goals.

Three population-goal components were assessed by both Cerhan et al. ${ }^{(6)}$ and Vossenaar ${ }^{(9)}$ using the pseudoindividualisation approach. For these three components in common, different evaluation methods and cut-off criteria were used. Vossenaar ${ }^{(9)}$ and Valdés-Ramos et al. ${ }^{(7)}$ used this method for seven components in common and used the same evaluation methods and cut-off criteria for all. The only component assessed in this manner by both Cerhan et al. ${ }^{(6)}$ and Valdés-Ramos et al. ${ }^{(7)}$ was 'total fats and oils to provide $15 \%$ to no more than $30 \%$ total energy' (recommendation 8 ), but different cut-off criteria were applied. A minimum value of $15 \%$ energy from fat was set in the two-nation Concordance $^{(9)}$ and Santa Rosa studies ${ }^{(7)}$, whereas in the Iowa study, subjects with a fat intake below $30 \%$ energy were not penalised.

\section{Quantitative challenges in interpreting the recommendations}

The major confounders for the evaluator trying to determine whether an individual - or a population - is following the WCRF/AICR recommendations are a series of quantitative inconsistencies between population goals and individual guidelines, further complicated by footnotes accompanying the original publication of the WCRF/AICR report ${ }^{(4)}$. Quantitative discrepancies in the recommended intake limits can be found in at least five recommendations according to the units chosen (Table 5).

The following examples illustrate some of the potential problems:

An adult woman who reports consuming $850 \mathrm{~g}$ starch or protein-rich foods of vegetable origin would not be concordant with the individual guideline to consume between 600 and $800 \mathrm{~g}$ cereals, pulses, roots, tubers and plantains, since she would be exceeding the recommended range. However, she would be classified as adhering if the seven-portion criterion of the same foods, which has no upper limit, were taken as the operative cut-off.

An adult man who reports consuming $820 \mathrm{~g}$ fruits and vegetables per $d$ would be above the acceptable range, with its $800 \mathrm{~g}$ upper limit. However, if the operative criterion were based on the expression in ounces, his $820 \mathrm{~g}$ would classify his intake as appropriate. The latter classification would also apply with the more-than-seven portion criterion, which is open ended, and has no upper limit. In a practical, survey sense, if data are clustered close to the boundary criteria levels, prevalences of concordant and non-concordant individuals in a sample could vary greatly depending on which of the expressions have been used to create the operative criteria for evaluation.

\section{Quantitative directions}

The primary recommendations calling for dietary change range from widespread vagueness, lack of quantitative specificity (or boundaries) to internal numerical inconsistencies when intake levels are provided. The three investigative groups ${ }^{(6,7,9)}$ have grappled with setting operative criteria and have often arrived at diverse cut-offs for the same recommendation components.

Quantitative uncertainty might evoke some confusion on the part of a consumer attempting to follow the guidance of the WCRF/AICR guidance. They might ask themselves: 'When is my diet varied? What is minimally processed food?' For the consumer these descriptions are generally subjective in their interpretation. For the evaluator, trying to classify behaviour as concordant, specific quantification is a requisite and some established cut-off criterion must be applied. Similarly, although a consumer may understand 'year round' and balance consistent intake across the year, establishing the continual nature of an eating behaviour in an evaluation instrument proved to be exceptionally challenging, requiring staggering of the survey throughout a calendar year. The vagueness of language also applies to individual recommendations such as 'limit consumption' and 'consume modest amounts' as in recommendation 8.

For at least a single recommendation (on sugar consumption) there was a general default consensus on the part of all three investigative $\operatorname{groups}^{(6,7,9)}$ to use the boundaries of $10 \%$ energy contribution for sugar. Cerhan et al. (6) also applied the $6 \mathrm{~g}$ of salt boundary from the population-goal level to individuals, while the other two groups ${ }^{(7,9)}$ felt that their instruments could not quantify salt or $\mathrm{Na}$ consumption.

Recommendation 1 illustrates an interesting conflating of the population goal and the individual guideline in the semantic sense. For example, the phrase 'choose predominantly plant-based diets' for individuals could be interpreted as anything greater than $50 \%$ of intake from foods and beverages of plant origin or it could be calculated on a foodweight basis or a food-energy basis; the framers provide no guidance. Vossenaar ${ }^{(9)}$ operationalised this cut-off on a weight ( $\mathrm{g}$ food) basis given that individual guidelines are expressed in $g$ amounts (Table 1). If we look at the corresponding population goal, 'based primarily on foods of plant origin', we would have to take the same semantic interpretation for a target group average, as we have for an individual goal. Hence, a population with the vast majority of its members being individually concordant would have a distribution for the plant:animal ratio shifted far to the left of a normative curve for which $51 \%$ was the population mean.

At least two phrases in the individual recommendations leave doubt as to whether they represent health-promoting obligations or merely alternative, helpful suggestions. For recommendation 8 , on meat consumption the individual guideline states 'it is preferable to choose fish, poultry or meat from non-domesticated animals in place of red meat'. For recommendation 9, on salt and salting, the individual recommendation text reads 'use herbs and spices to season foods'. A common-sense interpretation of this language might be that they merely constitute 'menu suggestions', with no imperative force. $\operatorname{Vossenaar}^{(9)}$, at least, actually 
Table 3. Summary of the 1997 World Cancer Research Fund/American Institute of Cancer Research recommendations and the ability to assess them by means of the field-study and case-control study questionnaires used by Valdés-Ramos et al. ${ }^{(8) \star}$

\begin{tabular}{lll}
\hline Variable of interest & Field study $\dagger$ & Case-control study $\dagger$ \\
\hline Nutritional adequacy & + & + \\
Dietary variety & +- & $+1-$ \\
Contribution of edible plants to diet & + & + \\
BMI & - & $-\ddagger$ \\
Physical activity level & - & + \\
Intake & + & + \\
$\quad$ Fruit and vegetables & + & + \\
$\quad$ Cereals, tubers and legumes & + & + \\
Sugar & + & + \\
Ethanol & + & + \\
$\quad$ Red meat & + & - \\
Fat & - & - \\
$\quad$ Salt & + & - \\
Dietary supplements & - & - \\
Sungal contamination of food & - & - \\
Chemical contamination of food & - & - \\
Charring of fish and meat & - & \\
\hline
\end{tabular}

* Reproduced with permission from Valdés-Ramos et al. ${ }^{(8)}$

† Variables are ranked as follows: + , evaluated; +/-, could be evaluated; - , not evaluated.

$\ddagger$ Assessed via anthropometry and total energy expenditure estimation.

applied an operative criterion for the recommendation to prefer alternative meats (see Appendix 1), determining whether $51 \%$ of flesh intake was in the alternate classes of fish and seafood or fowl. Since the salt recommendation was not evaluated by Vossenaar ${ }^{(9)}$, the issue of spices substitution remains moot.

Table 5 illustrates that the varying ways of rephrasing some of the explicitly numerical goals do not provide strict quantitative equivalency. An individual who had all of their drinks of alcoholic beverages as wine would consistently have $40 \%$ greater ethanol intake than one who consumed spirits. Equally troubling for the choice of evaluation criteria are the open-end $v$. the bounded criteria for daily intakes of healthful food groups such as fruits and vegetables (recommendation 4) and other plant foods (recommendation 5). Of course, there are reciprocal

Table 4. Summary of the 1997 World Cancer Research Fund/American Institute of Cancer Research (WCRF/AICR) recommendations and the operationalisation criteria and evaluation categories used by Cerhan et al. ${ }^{(6) \star}$

\begin{tabular}{|c|c|c|c|}
\hline \multicolumn{2}{|c|}{ Recommendation } & \multirow[t]{2}{*}{ Operationalisation } & \multirow[t]{2}{*}{ Categories } \\
\hline 1. & Food supply and eating & & \\
\hline \multirow[t]{2}{*}{2.} & Body weight & BMI at baseline (1986) & $\begin{array}{l}<25 \cdot 0 \mathrm{~kg} / \mathrm{m}^{2} \\
>25 \cdot 0 \mathrm{~kg} / \mathrm{m}^{2}\end{array}$ \\
\hline & & Weight gain since age 18 years & $\begin{array}{l}\text { Gained }<11 \text { pounds } † \\
\text { Gained }=11 \text { pounds } \dagger\end{array}$ \\
\hline 3. & Physical activity & Usual recreational physical activity at baseline (1986) & $\begin{array}{l}\text { Active } \\
\text { Not active }\end{array}$ \\
\hline 4. & Vegetables and fruits & Daily vegetable and fruit consumption, excluding pulses and starchy vegetables & $\begin{array}{l}<\text { Five servings/d } \\
=\text { Five servings } / \mathrm{d}\end{array}$ \\
\hline 5. & Other plant foods & Daily intake of complex carbohydrates $>400 \mathrm{~g}$ (about 80 th percentile) & $\begin{array}{l}<400 \mathrm{~g} \\
\geq 400 \mathrm{~g}\end{array}$ \\
\hline 6. & Alcoholic drinks & Daily alcohol intake (one drink about $14 \mathrm{~g}$ alcohol) & $\begin{array}{l}<14 \mathrm{~g} \\
>14 \mathrm{~g}\end{array}$ \\
\hline 7. & Meat & Daily red meat intake (beef, lamb, pork and products from these meats) & $\begin{array}{l}<80 \mathrm{~g} \\
>80 \mathrm{~g}\end{array}$ \\
\hline 8. & Total fats and oils & Daily consumption of fat as percentage total energy & $\begin{array}{l}=30 \% \\
>30 \%\end{array}$ \\
\hline 9. & Salt and salting & Daily $\mathrm{Na}$ consumption from diet questionnaire, plus use of table salt & $\begin{array}{l}<2400 \mathrm{mg} \\
=2400 \mathrm{mg}\end{array}$ \\
\hline \multirow{6}{*}{$\begin{array}{l}10 . \\
11 . \\
12 . \\
13 . \\
14 .\end{array}$} & Storage & Not included & \\
\hline & Preservation & Not included & \\
\hline & Additives and residues & Not included & \\
\hline & Preparation & Not included & \\
\hline & Dietary supplements & Not included & \\
\hline & Tobacco & Ever $v$. never smoked cigarettes & $\begin{array}{l}\text { Never smoked } \\
\text { Ever smoked }\end{array}$ \\
\hline
\end{tabular}

*Adapted from Cerhan et al. ${ }^{(6)}$. 


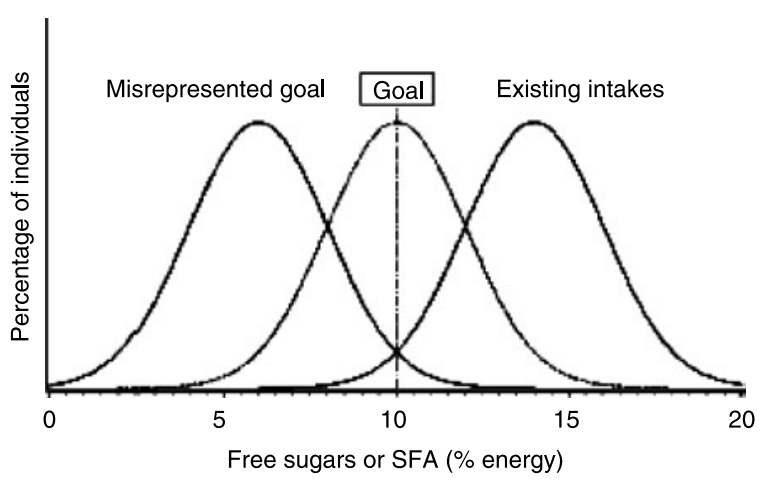

Fig. 1. Distinction between a population goal and an individual goal. The distribution of free sugars and SFA for three hypothetical populations, corresponding to: (1) an existing population whose intake of free sugars and SFA is higher than recommended by the joint WHO/FAO Expert Consultation ${ }^{(11)}$ (right), (2) a population that has achieved the population cut-off of $10 \%$ of energy as free sugars and SFA (centre), and (3) a population in which nearly all individuals have an intake less than $10 \%$, a situation that describes the result of misrepresentation of the population goal as an individual goal (left) (adapted from the report of the WHO Study Group $\left.{ }^{(11)}\right)$. Reproduced with permission from Nishida et al. ${ }^{(10)}$.

interactions within an individual consumer based on anatomical and physiological considerations. With a conventional three or four food intake eating pattern, satiety and gastric capacity would constrain consumptions of upwards of $1600 \mathrm{~g}$ of high-bulk and watery food items.

Staying with recommendation 4 , the WCRF/AICR report $^{(4)}$ specified that only a single $80 \mathrm{~g}$ serving of a natural fruit juice could be counted toward a day's fruit and vegetable allotment. The remainder had to be in a solid form. The underlying epidemiological or physiological basis for the non-equivalence of juiced or solid fruits and vegetables is not clear. Recently, Ruxton et al. ${ }^{(13)}$ reviewed the literature with a tentative conclusion that natural juices have the same preventive potency against chronic disease as their solid counterparts.

\section{Reforming approaches to set operative criteria for population goals}

Nishida et al. ${ }^{(10)}$ provide a beacon of clarity for what could be considered an orthodox approach to assessing populations for their concordance or compliance with population goals, when they are expressed in quantitative terms as a target population mean. A corollary of the Nishida logic, moreover, is that a representative sample of a population or subpopulation would be ideal for the application of population-goal criteria. Hence, in this regard, all of the publications considered are convenience samples and would not strictly apply as subjects of an orthodox population-goal analysis. This caveat notwithstanding, Valdés-Ramos et al. ${ }^{(7)}$ generally pursued the population-average assessment. Vossenaar ${ }^{(9)}$, on the other hand, applied the population goal both as a target average at the wholesample level and as a cut-off criterion at the individualsubject level.
At the level of assessing recommendation 1, related to dietary adequacy, both Valdés-Ramos et al. ${ }^{(7)}$ and Vossenaar $^{(9)}$ assessed individuals against the respective national standards for individual intake (for example, intake levels that would meet the requirements of $95-97.5 \%$ of the healthy population). The population was assessed, however, as the percentage of individuals achieving national standards, which is the concept utilised within the EAR for a reference population ${ }^{(12)}$, which has been adopted by the Food and Nutrition Board of the Institute of Medicine of the United States in its Dietary Reference Intakes ${ }^{(14)}$. These EAR represent target mean nutrient intakes for normal, free-living North Americans in the USA and Canada. More recently, an adaptation of EAR for the global population has appeared within the UN system ${ }^{(15)}$. The EAR would be applied as populationgoal intakes to evaluate the adequacy of the diet, in compliance or concordance with the first element of recommendation 1 .

Recommendation 3 calls for 'an active lifestyle equivalent to a physical activity level (PAL) of at least 1.75 , with opportunities for vigorous physical activity'. Consistent with the Nishida-derived approach, the population-goal evaluation would seek to determine if the population sample had a physical activity level of 1.75. Based on the age, sex and body size of individuals in the population, one could estimate the underlying basal energy expenditure. The prescription of the WCRF/AICR ${ }^{(4)}$ would be that at least half the population expends energy in physical activity of three-quarters or more of their basal energy expenditure. Although diagnostic techniques to estimate total energy expenditure and expenditure due to physical activity exist ${ }^{(14)}$, none of them would be practically applied to a free-living population. Until a valid and reliable method for assessing individual activity-related energy expenditure is developed, WCRF/AICR recommendation 3 may elude evaluation at the population level. The second component criterion of 'opportunities for vigorous physical activity', interpreted literally, is not about behaviour; rather, it is about the social-physical environment. If, for instance, it is a social need for a rural adult population to carry water or chop firewood, then opportunities would be in place. For the rural middle class, the availability of exercise gymnasiums or running paths in the park would set the basis for meeting this 'opportunities' component criterion.

Recommendation 9 relates to salt and salting. Parsing the structure of the phrasing: 'Salt from all sources should amount to less than 6 grams/day ( 0.25 ounces) for adults', this clearly seems to be about an upper limit boundary criterion. The language of the footnote for children, which specifies less than $3 \mathrm{~g} / 1000 \mathrm{kcal}(0.72 \mathrm{~g} / 1000 \mathrm{~kJ})$, is consistent as a boundary prescription. For a population to be compliant, therefore, it would not be half of the population - but rather all of the population - to have a salt intake below the criterion. There is some confusion, however, between the reference to 'salt' (sodium chloride) from all sources, as referred to by the WCRF/AICR ${ }^{(4)}$, as all sources of 'sodium'; Asian cuisine, of course, uses other $\mathrm{Na}$ salts, notably sodium glutamate, which would not be covered in any way by the present phrasing of 


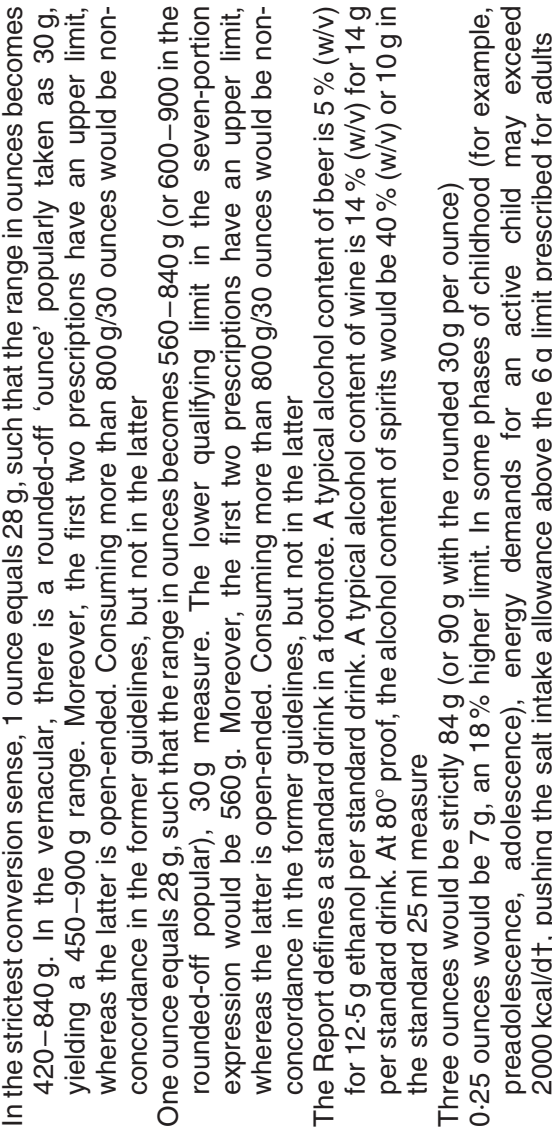

recommendation 9's population goal. In terms of an assessment of compliance or concordance with the salt and salting recommendation, surveying a representative population sample for $24 \mathrm{~h} \mathrm{Na}$ excretion could provide the classification. It is known from basic physiology that individuals in normal $\mathrm{Na}$ balance excrete over a $24 \mathrm{~h}$ period the amount of $\mathrm{Na}$ that they take in through their diet ${ }^{(16)}$. It would be an expensive and cumbersome task to collect complete $24 \mathrm{~h}$ urine collections in a free-living setting. Moreover, the population falls out of concordance if a single individual in the sample is found to have more than the equivalence of $6 \mathrm{~g}$ of salt's worth of $\mathrm{Na}$ in his or her urine specimen. For children, the logistics would be far more severe, with the need to assess dietary energy intake and make accurate urine collections in the more challenging setting of a juvenile population.

It seems possible that recommendation 10 which states, 'store perishable food in ways that minimize fungal contamination' can be evaluated at the population level, but not in any survey of individual behaviour. The guidance is aimed at avoiding exposures to carcinogenic mycotoxins. For a given population, exposure would be conditional on the appropriate ambient climatic conditions for fungal growth and for reliance of the population on large intakes of susceptible grains or legumes. In the case of this recommendation, the locus of evaluation would not be in a surveyed population, but rather through systematic evaluation of the operative storage practices.

With respect to recommendation 11 , the mandate to keep perishable foods chilled or frozen is inherently dependent on the infrastructure for refrigeration available to a society, and its appropriate use to preserve foods and prevent generation of carcinogenic toxins. In the evaluation, a proxy measure would be the reach and efficiency of refrigeration. On the one hand, if there are large gaps in the cooling and freezing systems, then the criterion could not be met. So, a systematic distribution of refrigeration could be the point of entry for population screening. If the population infrastructure is in place, proper use of refrigeration, such as temperature and storage of potentially problematic food items (for example, leftovers) are difficult to assess.

The status of exposure of a population to the carcinogenic effects of additives, pesticides, pesticide and other chemical contaminants is the basis of recommendation 12. However, such exposures are usually beyond the scope of the routine dietary survey investigations. Hence, this recommendation was omitted from consideration in the design of the Concordance Study $^{(9)}$ for Europe as well as that of Valdés-Ramos et al. ${ }^{(7)}$ in Guatemala. In a broader consideration, however, there are sources for inquiry for the characterisation of a population as in or out of compliance with established international and local standards. This would begin at the various ministries in a country ranging from health and agriculture to environmental safety, and the specific regulatory bodies within these governmental entities. In the era of international food trade, the caveat of determining practices in the places of food production and processing, which might be overseas, arises as a final challenge in addressing this point. 


\section{Summary and reflections}

Investigators need to continue to measure compliance and concordance with the WCRF/AICR tenets in free-living individuals. Such analysis will assist in the monitoring of dietary and health trends across populations, help to identify population-specific health education targets and also evaluate health interventions. Since the submission of the present paper for publication, the WCRF has published a new set of eight recommendations at two levels: public health goals and personal recommendations ${ }^{(5)}$. In this new report, population goals are set within a time range of 10 years, for example, 'population average consumption of sugary drinks to be halved every 10 years'. This makes the monitoring over a 10-year time frame essential for the assessment of concordance and provides a further challenge for nutritional epidemiologists.

Agencies who make recommendations and guidelines also need to think about monitoring procedures and to identify practical ways of working with the research community. The process of operationalisation of evaluation criteria for dietary recommendations is not new. Assessing concordance with healthy eating guidelines is problematic, and similar difficulties are encountered in, for example, the 'Healthy Eating Index ${ }^{\text {(17) }}$ which assesses concordance with the American dietary guidelines 'My Pyramid'(18). Similar questions, such as 'what does $<10 \%$ energy actual mean?' arise. The WCRF/AICR recommendations ${ }^{(4)}$ are global, making assessment more complex because they include more than just food-based dietary guidelines, i.e. physical activity, body weight, food preparation methods, etc. Then again, assessment is simplified by the unity of recommendations across sexes (with the exception of alcohol), age and body weight. Most assessment instruments have a scoring protocol, which raises issues such as which components are relevant within a given population, the weightings given to each behaviour and possible modifying effects of different behaviours (for example, can high levels of activity reduce the risk posed by inappropriate dietary choices).

The WCRF/AICR recommendations are aimed at guiding both individuals and populations (public health); assessment procedures need to take account of this. Specific applications dictate the locus of analysis. For regression analyses, such as in the Iowa study ${ }^{(6)}$, in which an individual outcome (cancer diagnosis) is the variable, evaluation must take place at the individual level. When it comes to populations, both options are theoretically possible. For instance, until the advent of the dietary reference intakes ${ }^{(14)}$, it was standard practice in dietetic research to report the prevalence of individuals exceeding - or failing to meet the RDA criterion ${ }^{(19)}$. This manner of assessing populations has given way, however, to the comparison of the measured group average with the EAR ${ }^{(12)}$. The analogous advocacy for evaluating health guideline behaviour in populations must make reference to the population goals (such as is found in the work of Nishida et al. ${ }^{(10)}$ (Fig. 1)). So, it is not a matter of 'either, or' but rather how each level of recommendations can best be probed by appropriate survey instruments.

There are no simple answers for the design of foodfrequency instruments aimed at assessing concordance of actual behaviours with recommended behaviours. However, sharing difficulties and building on the tools that have been developed from the four-nation Concordance Project should help the process to evolve. The jury is still out as to whether adapting the outputs of population surveys for evaluations of concordance to cancer-prevention recommendations or the design of specific questionnaires to test the recommendations will be the most appropriate approach. However, further judgements on the evaluation process will be possible following publication in the literature of the results of the Concordance Project.

\section{Acknowledgements}

We thank the American Institute for Cancer Research, the International Nutrition Foundation and Akzo Nobel for their financial support.

We are grateful to Dr Odilia Bermudez for her useful comments on the manuscript.

The authors are not aware of any conflicts of interest relating to this paper.

M. V. led on data collection, analysis, presentation and manuscript preparation; N. W. S. led on paper conceptualisation, data analysis and manuscript preparation; R. V.-R. contributed to paper conceptualisation, data analysis and manuscript preparation; A. S. A. contributed to paper conceptualisation, discussion and manuscript preparation.

\section{References}

1. World Health Organization (2002) Diet, Physical Activity and Health. Geneva: WHO.

2. Uauy R \& Solomons N (2005) Diet, nutrition, and the lifecourse approach to cancer prevention. J Nutr 135, Suppl., 2934S-2945S.

3. Mellstedt $\mathrm{H}$ (2006) Cancer initiatives in developing countries. Ann Oncol 17, Suppl. 8, viii24-viii31.

4. World Cancer Research Fund \& American Institute of Cancer Research (1997) Diet, Nutrition and Prevention of Human Cancer: A Global Perspective. Washington, DC: WCRF/AICR.

5. World Cancer Research Fund \& American Institute of Cancer Research (2007) Food, Nutrition, Physical Activity and the Prevention of Cancer: a Global Perspective. Washington, DC: WCRF.

6. Cerhan JR, Potter JD, Gilmore JM, et al. (2004) Adherence to the AICR cancer prevention recommendations and subsequent morbidity and mortality in the Iowa Women's Health Study cohort. Cancer Epidemiol Biomarkers Prev 13, 1114-1120.

7. Valdés-Ramos R, Cervantes I, Mendoza-Perdomo I, et al (2006) Concordance of diets and eating practices in a rural Guatemalan setting with the cancer prevention recommendations of the World Cancer Research Fund: estimates from existing dietary intake. Asia Pac J Clin Nutr 15, 259-266.

8. Valdés-Ramos R, Solomons NW, Anderson AS, et al. (2001) Can the degree of concordance with recommendations for a cancer prevention diet and lifestyle be assessed from existing survey information data? Am J Clin Nutr 74, 848-851.

9. Vossenaar M (2005) Concordance with global dietary and lifestyle recommendations to reduce cancer risk in two European populations. PhD Thesis, University of Dundee. 
10. Nishida C, Uauy R, Kumanyika S, et al. (2004) The joint WHO/FAO expert consultation on diet, nutrition and the prevention of chronic diseases: process, product and policy implications. Public Health Nutr 7, 245-250.

11. World Health Organization (2003) Diet, Nutrition and the Prevention of Chronic Diseases. Joint WHO/FAO Expert Consultation. WHO Technical Report Series no. 916. Geneva: WHO.

12. Murphy SP \& Poos MI (2002) Dietary reference intakes: summary of applications in dietary assessment. Public Health Nutr 5, 843-849.

13. Ruxton CH, Gardner EJ \& Walker D (2006) Can pure fruit and vegetable juices protect against cancer and cardiovascular disease too? A review of the evidence. Int J Food Sci Nutr 57, 249-272.

14. Institute of Medicine (2002) Dietary Reference Intakes for Energy, Carbohydrate. Fiber, Fat, Fatty Acids, Cholesterol, Protein, and Amino Acids. Washington, DC: National Academy Press.

15. World Health Organization \& Food and Agriculture Organization (2006) Guidelines on Food Fortification with Micronutrients. Geneva: WHO/FAO.

16. Melse-Boonstra A, Rozendaal M, Rexwinkel H, et al. (1998) Determination of discretionary salt intake in rural Guatemala and Benin to determine the iodine fortification of salt required to control iodine deficiency disorders: studies using lithium-labeled salt. Am J Clin Nutr 68, 636-641.
17. Guenther PM, Krebs-Smith SM \& Reedy J (2007). Development and Evaluation of the Healthy Eating Index2005. http://www.cnpp.usda.gov/healthyeatingindex.htm

18. US Department of Agriculture \& Center for Nutrition Policy and Promotion (2006) My Pyramid Tracker. http://www. mypyramidtracker.gov/

19. Food and Nutrition Board \& Institute of Medicine (2000) The Dietary Reference Intakes: Applications in Dietary Assessment. Washington, DC: National Academy Press.

20. Valdes-Ramos R, Solomons NW, Anderson AS, et al. (2001) Can the degree of concordance with recommendations for a cancer prevention diet and lifestyle be assessed from existing survey information data? Am J Clin Nutr 74, 848-851.

21. Willett WC, Sampson L, Stampfer MJ, et al. (1985) Reproducibility and validity of a semiquantitative food frequency questionnaire. Am J Epidemiol 122, 51-65.

22. Kushi LH, Fee RM, Folsom AR, et al. (1997) Physical activity and mortality in postmenopausal women. JAMA 277, 1287-1292.

23. Health Council of the Netherlands (2000) Dietary Reference Values: Calcium, Vitamin D, Thiamin, Riboflavin, Niacin, Pantothenic Acid, and Biotin. The Hague: Health Council of the Netherlands.

24. Health Council of the Netherlands (2001) Dietary Reference Intakes: Energy, Proteins, Fats and Digestible Carbohydrates. The Hague: Health Council of the Netherlands.

25. Health Council of the Netherlands (2003) Dietary Reference Intakes: Vitamin $B_{6}$, Folic Acid, and Vitamin $B_{12}$. The Hague: Health Council of the Netherlands. 


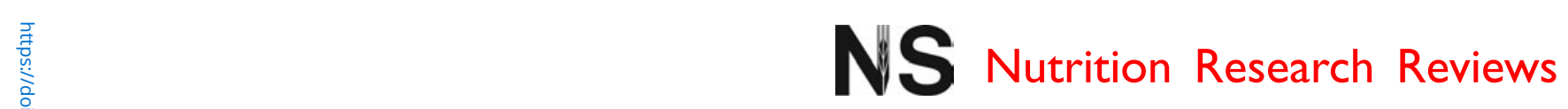

Appendix 1. A comparison of evaluation criteria for each World Cancer Research Fund/American Institute for Cancer Research (WCRF/AICR) recommendation by global research groups

Cerhan et al. (2004)

\begin{tabular}{|c|c|c|c|c|c|c|}
\hline & & & & & & \multirow[b]{2}{*}{ Evaluation } \\
\hline \multicolumn{2}{|c|}{ WCRF/AICR recommendation } & Evaluation method & Cut-off criteria & Evaluation method & Cut-off criteria & \\
\hline \multicolumn{7}{|c|}{ 1. Food supply and eating } \\
\hline & \multirow[t]{4}{*}{ Nutritionally adequate diets } & \multirow{4}{*}{ Not evaluated } & & & Population goal \\
\hline & & & & $\begin{array}{l}\text { Nutrient adequacy of energy, } \\
\text { macronutrients and twelve } \\
\text { selected micronutrients using } \\
\text { the Dutch RDA/Al }{ }^{23-25)} \\
\text { (mean for the sample) }\end{array}$ & $\begin{array}{l}\text { Mean intake as a pro- } \\
\text { portion of RDA/Al }\end{array}$ & $\begin{array}{l}\text { Nutrient adequ } \\
\text { selected micr } \\
\text { using the Gu } \\
\text { dietary recom } \\
\text { (INCAP) (me } \\
\text { sample) }\end{array}$ \\
\hline & & & & Pseudo-individualised & & Pseudo-individu \\
\hline & & & & $\begin{array}{l}\text { population goal } \\
\text { Not evaluated }\end{array}$ & & $\begin{array}{l}\text { lation goal } \\
\text { Nutrient adeq } \\
\text { selected mic } \\
\text { using the Gu } \\
\text { dietary recon } \\
\text { (INCAP) (by }\end{array}$ \\
\hline \multirow[t]{3}{*}{$1 \mathrm{~b}$} & \multirow[t]{3}{*}{ Varied diets } & \multirow[t]{3}{*}{ Not evaluated } & & $\begin{array}{l}\text { Population goal } \\
\text { Not evaluated }\end{array}$ & & \multirow[t]{3}{*}{$\begin{array}{l}\text { Population goal } \\
\text { Not evaluated }\end{array}$} \\
\hline & & & & $\begin{array}{l}\text { Pseudo-individualised } \\
\text { population goal }\end{array}$ & & \\
\hline & & & & $\begin{array}{l}\text { The percentage of food } \\
\text { items consumed at least } \\
\text { weekly (by individual) }\end{array}$ & Highest tertile & \\
\hline \multirow[t]{2}{*}{$1 \mathrm{c}$} & \multirow{2}{*}{$\begin{array}{l}\text { Based primarily on } \\
\text { foods of plant origin }\end{array}$} & \multirow[t]{2}{*}{ Not evaluated } & & Population goal & & \multirow{2}{*}{$\begin{array}{l}\text { Population goal } \\
\text { Not evaluated }\end{array}$} \\
\hline & & & & $\begin{array}{l}\text { Not evaluated } \\
\text { Pseudo-individualised } \\
\text { population goal } \\
\text { See li }\end{array}$ & & \\
\hline li & $\begin{array}{l}\text { Choose predominantly } \\
\text { plant-based diets }\end{array}$ & Not evaluated & & $\begin{array}{l}\text { The ratio of estimated daily } \\
\text { intakes of foods from plant } \\
\text { origin to foods from animal } \\
\text { origin }\end{array}$ & $>0.5$ & Not evaluated \\
\hline lii & $\begin{array}{l}\text { Rich in a variety of vegetables } \\
\text { and fruits, pulses (legumes) } \\
\text { and minimally processed } \\
\text { starchy staple foods }\end{array}$ & Not evaluated & & See IViii and $5 a$ & & Not evaluated \\
\hline \multicolumn{7}{|c|}{ 2. Maintaining body weight } \\
\hline \multirow[t]{3}{*}{$2 a$} & \multirow{3}{*}{$\begin{array}{l}\text { Population average body } \\
\text { mass indices throughout } \\
\text { adult life BMI } 21-23 \\
\text { (individuals BMI } \\
18.5-25 \text { ) }\end{array}$} & $\begin{array}{l}\text { Population goal } \\
\text { Not evaluated }\end{array}$ & & $\begin{array}{l}\text { Population goal } \\
\text { Self-reported BMI } \\
\text { (mean for the sample) }\end{array}$ & $21-23$ & \multirow[t]{3}{*}{ Not evaluated } \\
\hline & & $\begin{array}{l}\text { Pseudo-individualised } \\
\text { population goal }\end{array}$ & & $\begin{array}{l}\text { Pseudo-individualised } \\
\text { population goal }\end{array}$ & & \\
\hline & & $\begin{array}{l}\text { BMI at baseline } \\
\text { (1986) (by individual) }\end{array}$ & $\leq 25$ & $\begin{array}{l}\text { Self-reported BMI } \\
\text { (by individual) }\end{array}$ & $18 \cdot 5-25 \cdot 0$ & \\
\hline Ili & Avoid being underweight & Not evaluated & & Not evaluated & & Not evaluated \\
\hline & Avoid being overweight & Not evaluated & & Not evaluated & & Not evaluated \\
\hline Iliii & $\begin{array}{l}\text { Limit weight gain during } \\
\text { adulthood to less than } \\
5 \mathrm{~kg} \text { (11 pounds) }\end{array}$ & $\begin{array}{l}\text { Weight gain since } \\
\text { age } 18 \text { years }\end{array}$ & $\begin{array}{c}\text { Gained }<11 \\
\text { pounds }\end{array}$ & $\begin{array}{l}\text { Weight gain since age } 18 \text { years } \\
\text { and in the previous } 10 \text { years } \\
\text { (subjects aged } \geq 28 \text { years old) }\end{array}$ & Gained $<5 \mathrm{~kg}$ & Not evaluated \\
\hline \multicolumn{7}{|c|}{ 3. Physical activity } \\
\hline \multirow[t]{3}{*}{ 3a } & \multirow{3}{*}{$\begin{array}{l}\text { Active lifestyle equivalent } \\
\text { to a physical activity level } \\
\text { (PAL) of at least } 1.75\end{array}$} & $\begin{array}{l}\text { Population goal } \\
\text { Not evaluated }\end{array}$ & & $\begin{array}{l}\text { Population goal } \\
\text { Not evaluated }\end{array}$ & & \multirow[t]{3}{*}{ Not evaluated } \\
\hline & & Pseudo-individualised & & Pseudo-individualised & & \\
\hline & & $\begin{array}{l}\text { population goal } \\
\text { Usual recreational } \\
\text { physical activity at } \\
\text { baseline (1986) (by } \\
\text { individual) }\end{array}$ & Active & $\begin{array}{l}\text { population goal } \\
\text { Total activity score } \\
\text { (MET-score) for activitites } \\
\text { at work, commuting activities, } \\
\text { household activities and } \\
\text { leisure time activities } \\
\text { (by individual) }\end{array}$ & $>10000 \mathrm{MET}-\mathrm{h} / \mathrm{d}$ & \\
\hline
\end{tabular}

Valdés-Ramos et al. $(2006)^{(7)}$

Cut-off criteria

ulation goal the Guatemalan proportion of nutrient rec-
ommendation

ualised popu-

Proportion of individuals below $100 \%$ of Guatemalan nutrient rec-

(by individual) 


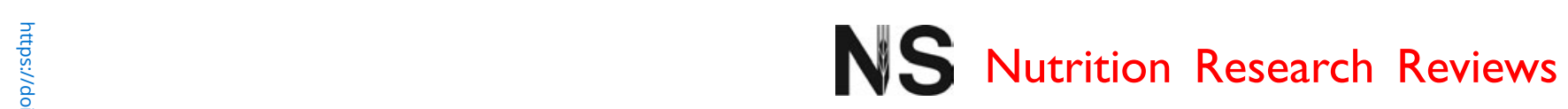

Appendix 1. Continued

\begin{tabular}{|c|c|c|c|c|c|c|c|}
\hline & & \multicolumn{2}{|c|}{ Cerhan et al. $(2004)^{(6)}$} & \multicolumn{2}{|c|}{ Vossenaar $(2005)^{(9)}$} & \multicolumn{2}{|c|}{ Valdés-Ramos et al. $(2006)^{(7)}$} \\
\hline \multicolumn{2}{|c|}{ WCRF/AICR recommendation } & Evaluation method & Cut-off criteria & Evaluation method & Cut-off criteria & Evaluation method & Cut-off criteria \\
\hline $3 b$ & $\begin{array}{l}\text { Opportunities for vigorous } \\
\text { activities }\end{array}$ & Not evaluated & & $\begin{array}{l}\text { Population goal } \\
\text { Not evaluated } \\
\text { Pseudo-individualised } \\
\text { population goal } \\
\text { See Illii }\end{array}$ & & Not evaluated & \\
\hline Illi & $\begin{array}{l}\text { If occupational activity is low } \\
\text { or moderate, take an hour's } \\
\text { brisk walk or similar exercise } \\
\text { daily }\end{array}$ & Not evaluated & & $\begin{array}{l}\text { Total activity score (MET-score) } \\
\text { for occupational activities }\end{array}$ & Highest tertile & Not evaluated & \\
\hline Illii & $\begin{array}{l}\text { Exercise vigorously for a total } \\
\text { of at least one hour in a week }\end{array}$ & Not evaluated & & $\begin{array}{l}\text { Activities with a MET-score } \\
\geq 6.5 \text { for adults aged } \\
18-55 \text { years old and } \\
\geq 5 \text { for adults aged above } \\
55 \text { years old }\end{array}$ & $\geq 1 \mathrm{~h} /$ week & Not evaluated & \\
\hline \multicolumn{8}{|c|}{ 4. Vegetables and fruits } \\
\hline \multirow{2}{*}{$\begin{array}{l}4 a \\
4 b\end{array}$} & Year-round consumption & NA & & Not evaluated & & Not evaluated & \\
\hline & Variety of vegetables and fruits & Not evaluated & & $\begin{array}{l}\text { Population goal } \\
\text { Not evaluated } \\
\text { Pseudo-individualised } \\
\text { population goal } \\
\text { See IViii }\end{array}$ & & $\begin{array}{l}\text { Population goal } \\
\text { Not evaluated } \\
\text { Pseudo-individualised } \\
\text { population goal } \\
\text { Not evaluated }\end{array}$ & \\
\hline \multirow[t]{3}{*}{$4 c$} & $\geq 7 \%$ of energy & Not evaluated & & $\begin{array}{l}\text { Population goal } \\
\text { Not evaluated }\end{array}$ & & $\begin{array}{l}\text { Population goal } \\
\text { Daily consumption of } \\
\text { vegetables and fruits } \\
\text { (including a maximum } \\
\text { of one portion of juice) } \\
\text { as percentage total } \\
\text { energy (mean for the } \\
\text { sample) }\end{array}$ & $>7 \%$ of energy \\
\hline & & & & $\begin{array}{l}\text { Pseudo-individualised } \\
\text { population goal }\end{array}$ & & $\begin{array}{l}\text { Pseudo-individualised } \\
\text { population goal }\end{array}$ & \\
\hline & & & & $\begin{array}{l}\text { Daily consumption of } \\
\text { vegetables and fruits } \\
\text { (including a maximum of } \\
\text { one portion of juice) as } \\
\text { percentage total energy } \\
\text { (by individual) }\end{array}$ & $>7 \%$ of energy & Not evaluated & \\
\hline IVi & $400-800 \mathrm{~g}$ ( $15-30$ ounces) & Not evaluated & & $\begin{array}{l}\text { Daily vegetables (excluding } \\
\text { potatoes and beans) and } \\
\text { fruit intake (including a maxi- } \\
\text { mum of one portion of juice) }\end{array}$ & $400-800 \mathrm{~g} / \mathrm{d}$ & Not evaluated & \\
\hline IVii & $\begin{array}{l}\text { Five or more portions } \\
\text { (servings) per d }\end{array}$ & $\begin{array}{l}\text { Daily vegetable and fruit } \\
\text { consumption, exclud- } \\
\text { ing pulses and starchy } \\
\text { vegetables }\end{array}$ & $\begin{array}{l}\geq \text { Five ser- } \\
\text { vings/d } \\
\text { (portion size } \\
\text { not specified) }\end{array}$ & $\begin{array}{l}\text { Daily vegetables (excluding pota- } \\
\text { toes and beans) and fruit } \\
\text { intake (including a maximum } \\
\text { of one portion of juice) }\end{array}$ & $\begin{array}{l}\geq \text { Five portions } / \mathrm{d} \text { (por- } \\
\quad \text { tion size } 80 \mathrm{~g} \text { ) }\end{array}$ & Not evaluated & \\
\hline IViii & $\begin{array}{l}\text { Variety of vegetables } \\
\text { and fruits }\end{array}$ & Not evaluated & & $\begin{array}{l}\text { Percentage of types of vegetables } \\
\text { (excluding potatoes and } \\
\text { beans) and fruits (excluding } \\
\text { fruit juices) consumed in the } \\
\text { previous week }\end{array}$ & Highest tertile & Not evaluated & \\
\hline \multirow{2}{*}{$\begin{array}{l}\text { 5. Othe } \\
5 a\end{array}$} & $\begin{array}{l}\text { Year-round consumption } \\
\text { er plant foods }\end{array}$ & Not evaluated & & Not evaluated & & Not evaluated & \\
\hline & $\begin{array}{l}\text { Variety of starchy or } \\
\text { protein-rich foods of plant } \\
\text { origin }\end{array}$ & Not evaluated & & $\begin{array}{l}\text { Population goal } \\
\text { Not evaluated }\end{array}$ & & Not evaluated & \\
\hline
\end{tabular}




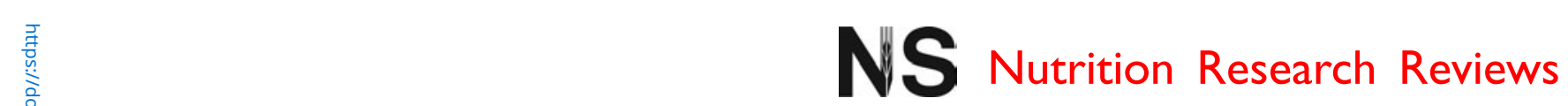

Appendix 1. Continued

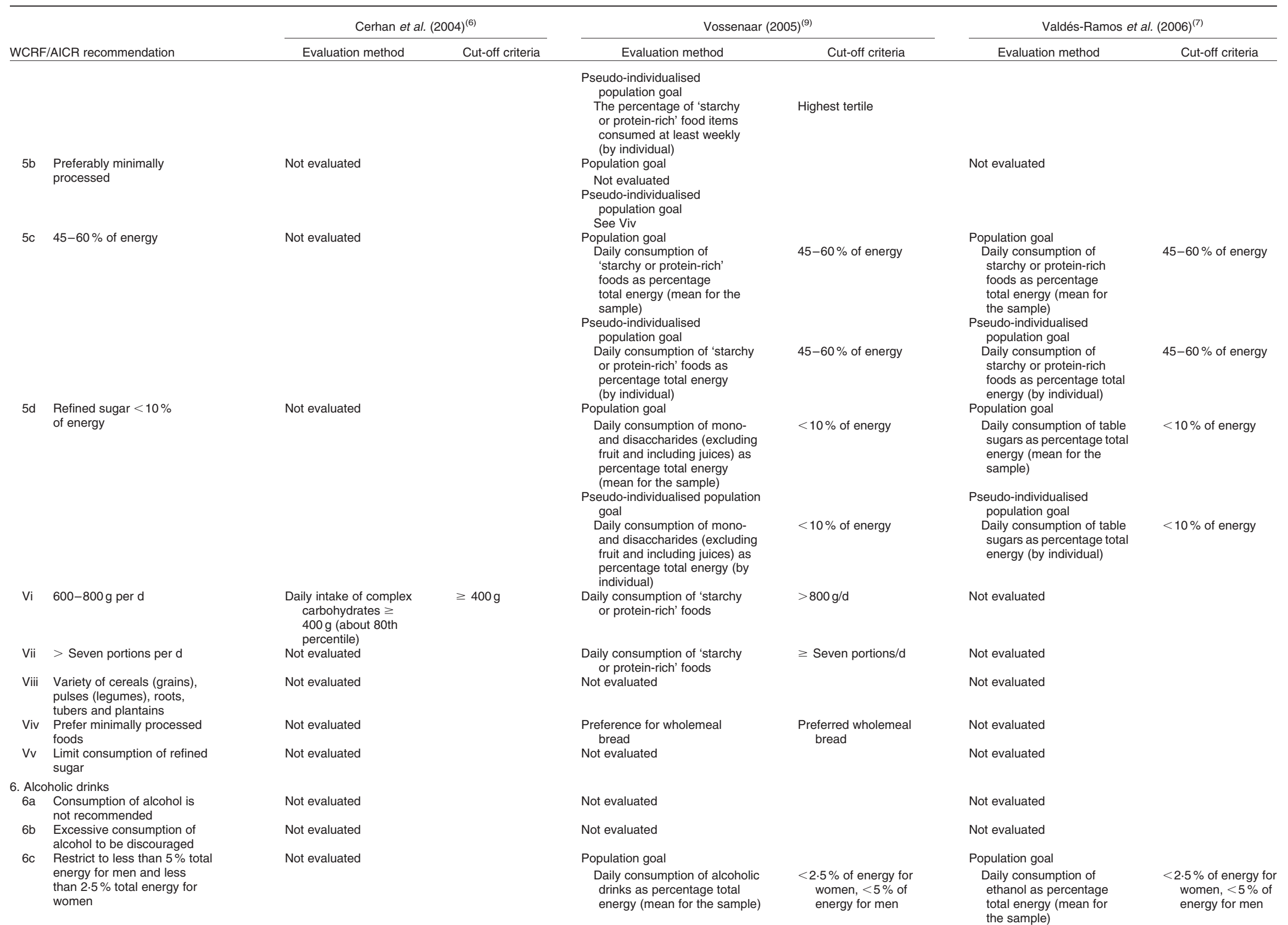




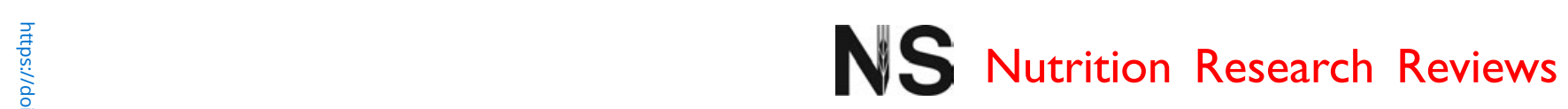

Appendix 1. Continued

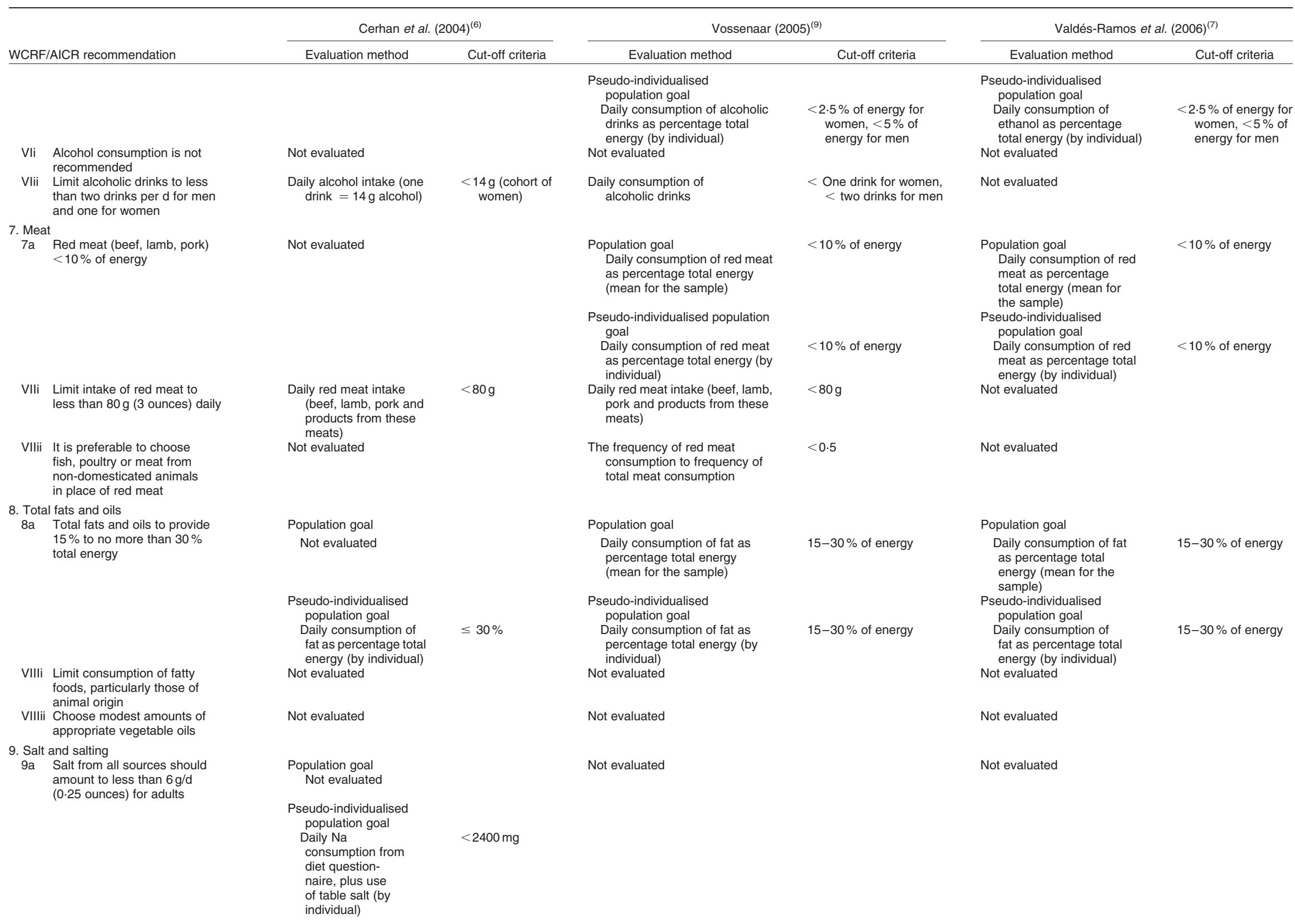




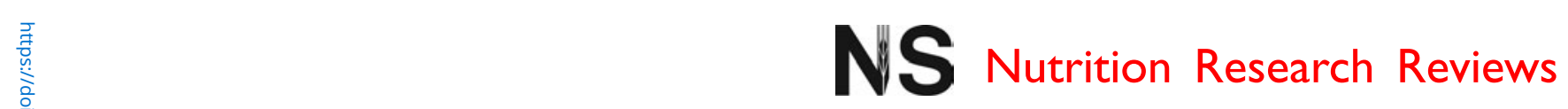

Appendix 1. Continued

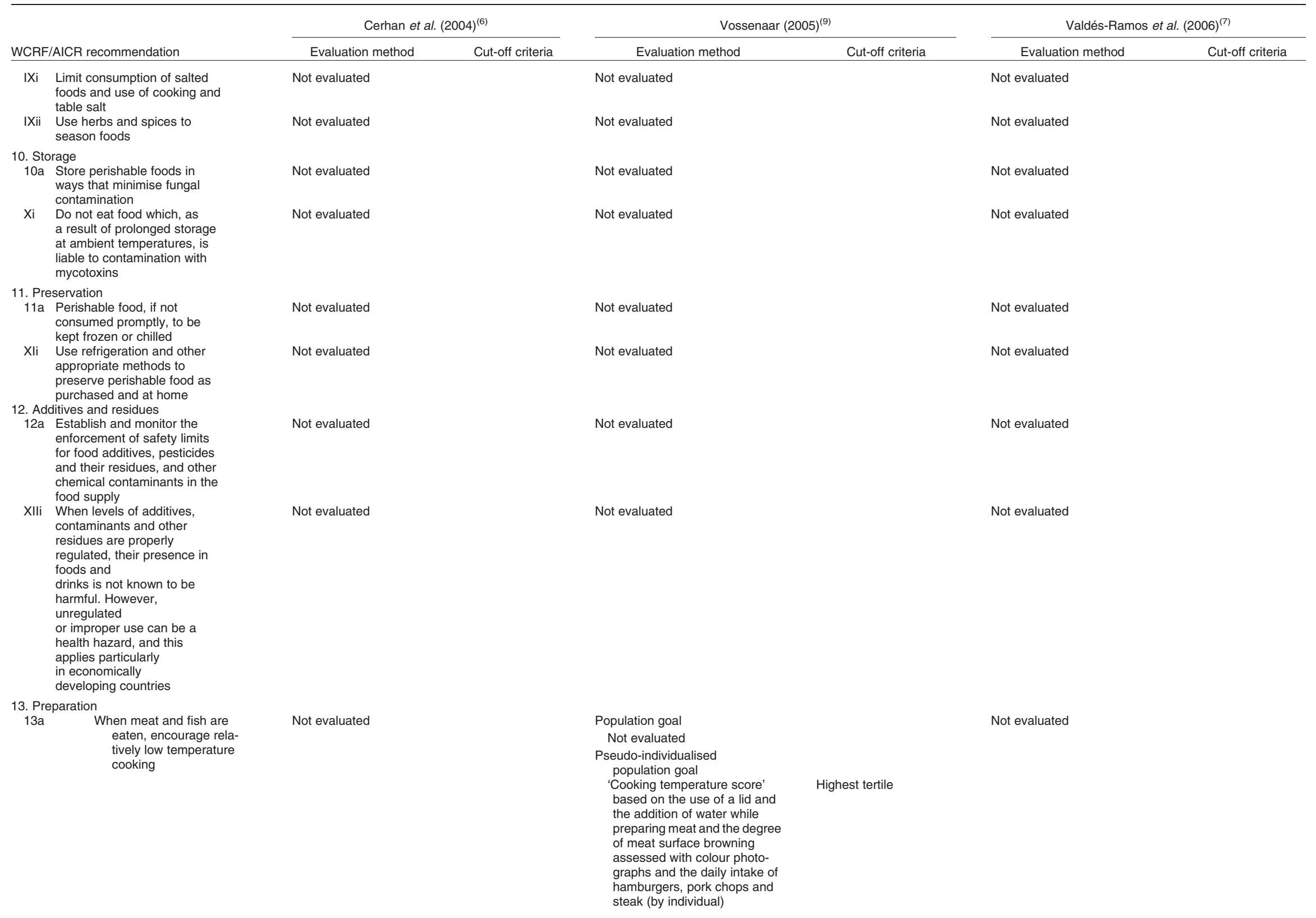




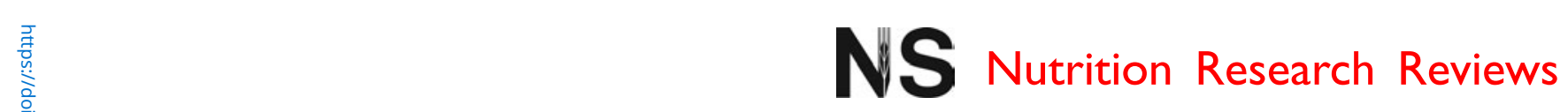

Appendix 1. Continued

\begin{tabular}{|c|c|c|c|c|c|c|c|}
\hline \multirow{2}{*}{\multicolumn{2}{|c|}{ WCRF/AICR recommendation }} & \multicolumn{2}{|c|}{ Cerhan et al. $(2004)^{(6)}$} & \multicolumn{2}{|c|}{ Vossenaar $(2005)^{(9)}$} & \multicolumn{2}{|c|}{ Valdés-Ramos et al. $(2006)^{(7)}$} \\
\hline & & Evaluation method & Cut-off criteria & Evaluation method & Cut-off criteria & Evaluation method & Cut-off criteria \\
\hline XIIII & Do not eat charred food & Not evaluated & & $\begin{array}{l}\text { The degree of browning preferred } \\
\text { for different types of red meat } \\
\text { based on photographs of } \\
\text { hamburgers, pork chops and } \\
\text { steaks cooked at } 225,200, \\
175 \text { and } 150^{\circ} \mathrm{C}\end{array}$ & Highest tertile & Not evaluated & \\
\hline XIIllii & $\begin{array}{l}\text { For meat and fish eaters, avoid } \\
\text { burning of meat juices }\end{array}$ & Not evaluated & & $\begin{array}{l}\text { Daily consumption of meat juices } \\
\text { and 'cooking temperature } \\
\text { score' of red meat described } \\
\text { above }\end{array}$ & Highest tertile & Not evaluated & \\
\hline XIIliii & $\begin{array}{l}\text { Consume the following only } \\
\text { occasionally: meat and fish grilled } \\
\text { (broiled) in direct flame; cured and } \\
\text { smoked meats }\end{array}$ & Not evaluated & & Not evaluated & & Not evaluated & \\
\hline \multicolumn{8}{|c|}{ 14. Dietary supplements } \\
\hline $14 a$ & $\begin{array}{l}\text { Community dietary pattern to be } \\
\text { consistent with reduction of cancer } \\
\text { risk without the use of dietary } \\
\text { supplements }\end{array}$ & Not evaluated & & Not evaluated & & Not evaluated & \\
\hline Tobacce & $\begin{array}{l}\text { For those who follow the rec- } \\
\text { ommendations presented here, } \\
\text { dietary supplements are probably } \\
\text { unnecessary, and possible unhelp- } \\
\text { ful, for reducing cancer risk }\end{array}$ & Not evaluated & & $\begin{array}{l}\text { Consumed supplements with the } \\
\text { purpose of preventing the } \\
\text { onset of cancer }\end{array}$ & Non-consumers & Not evaluated & \\
\hline Todacec & Discourage production, promotion & Not evaluated & & Not evaluated & & Not evaluated & \\
\hline & Do not smoke or chew tobacco & $\begin{array}{l}\text { Ever } v \text {. never smoked } \\
\text { cigarettes }\end{array}$ & Never & $\begin{array}{l}\text { Smokers (current or past) } v \text {. } \\
\text { non-smokers }\end{array}$ & Non-smokers & Not evaluated & \\
\hline
\end{tabular}

Al, adequate intake; INCAP, Institute of Nutrition of Central America and Panama; PAL, physical activity level; MET, metabolic equivalents; NA, not applicable. 


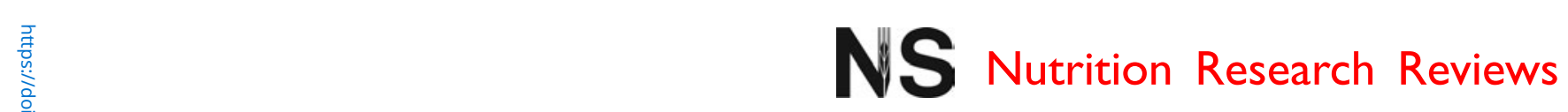

Appendix 2. A comparison of number of World Cancer Research Fund/American Institute for Cancer Research recommendations and component numbers evaluated by global research groups

\begin{tabular}{|c|c|c|c|c|c|c|}
\hline & \multicolumn{2}{|c|}{ Cerhan et al. (2004) ${ }^{(6)}$} & \multicolumn{2}{|c|}{ Vossenaar $(2005)^{(9)}$} & \multicolumn{2}{|c|}{ Valdés-Ramos et al. (2006) ${ }^{(7)}$} \\
\hline & $\begin{array}{l}\text { Number of } \\
\text { recommendations }\end{array}$ & $\begin{array}{l}\text { Component } \\
\text { numbers (total) }\end{array}$ & $\begin{array}{l}\text { Number of } \\
\text { recommendations }\end{array}$ & $\begin{array}{l}\text { Component } \\
\text { numbers (total) }\end{array}$ & $\begin{array}{l}\text { Number of } \\
\text { recommendations }\end{array}$ & $\begin{array}{l}\text { Component } \\
\text { numbers (total) }\end{array}$ \\
\hline Population goals & 4 & $2 a, 3 a, 8 a, 9 a(4)$ & 9 & $\begin{array}{l}1 \mathrm{a}, 1 \mathrm{~b}, 2 \mathrm{a}, 3 \mathrm{a}, 4 \mathrm{c}, 5 \mathrm{a}, 5 \mathrm{c}, 5 \mathrm{~d} \\
\quad 6 \mathrm{c}, 7 \mathrm{a}, 8 \mathrm{a}, 13 \mathrm{a}(12)\end{array}$ & 6 & $\begin{array}{l}1 \mathrm{a}, 4 \mathrm{c}, 5 \mathrm{c}, 5 \mathrm{~d}, 6 \mathrm{c}, 7 \mathrm{a} \\
\quad 8 \mathrm{a}(7)\end{array}$ \\
\hline Population goals & 0 & $(0)$ & 6 & $1 a, 2 a, 5 c, 5 d, 6 c, 7 a, 8 a(7)$ & 6 & $\begin{array}{l}1 \mathrm{a}, 4 \mathrm{c}, 5 \mathrm{c}, 5 \mathrm{~d}, 6 \mathrm{c}, 7 \mathrm{a}, \\
8 \mathrm{a}(7)\end{array}$ \\
\hline Pseudo-individual goals & 4 & $2 a, 3 a, 8 a, 9 a(4)$ & 9 & $\begin{array}{l}\text { 1b, 2a, 3a, 4c, 5a, 5c, 5d, 6c, } \\
\quad 7 \mathrm{a}, 8 \mathrm{a}, 13 \mathrm{a}(11)\end{array}$ & 5 & $\begin{array}{l}1 \mathrm{a}, 5 \mathrm{c}, 5 \mathrm{~d}, 6 \mathrm{c}, 7 \mathrm{a} \\
\quad 8 \mathrm{a}(6)\end{array}$ \\
\hline Individual guidelines & 6 & $\begin{array}{l}\text { Iliii, IVii, Vi, Vlii, VIIi, } \\
\text { tobacco (6) }\end{array}$ & 10 & $\begin{array}{l}\text { Ii, Iliii, IIli, Illii, IVi, IVii, IViii, Vi, } \\
\text { Vii, Viv, Vlii, VIlli, VIllii, XIIII, XIIlii, } \\
\text { XIVi, tobacco (17) }\end{array}$ & 0 & (0) \\
\hline Total & 9 & $(10)$ & 11 & (29) & 6 & (7) \\
\hline
\end{tabular}

